International Journal of Social Sciences and Humanities
Available online at http://sciencescholar.us/journal/index.php/ijssh
Vol. 3 No. 2, August 2019, pages: $24 \sim 30$
e-ISSN: 2550-7001, p-ISSN: 2550-701X
https://doi.org/10.29332/ijssh.v3n2.290

\title{
Professional Training Incident in Local Development
}

\author{
$\underset{\text { \&cicktor updates }}{\text { CrossMark }}$ \\ Yadira Chávez Loor ${ }^{a}$, José Leonardo Ávila Zambrano ${ }^{\mathrm{b}}$, María Dolores Chávez Loor ${ }^{\mathrm{c}}$, Carlos G. \\ Villacreses Viteri ${ }^{\mathrm{d}}$, María Rodríguez Gámez ${ }^{\mathrm{e}}$
}

Article history: Received 27 December 2018, Accepted: 30 April 2019, Published: 6 June 2019

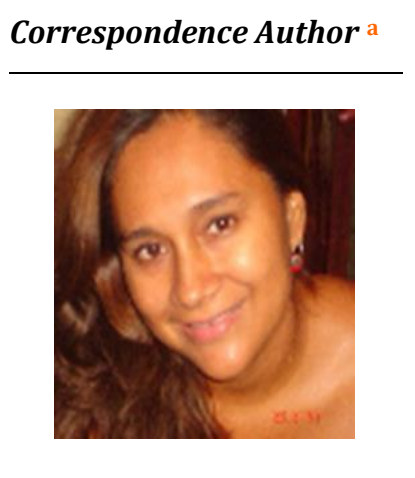

Keywords

agricultural activity;

local development;

professionals;

strategy;

university;

\begin{abstract}
If the concept, of the university, has taken as a reference it can be affirmed, that it is the academic institution of higher education, research, and relationship with society. Which grants academic degrees in different disciplines, in order to make the economic and social development of the community professionally viable, and the contribution it offers is practically essential, especially as it relates to the link between the human resource that leaves and its influence on the local development of the society. A conscientious study has made the indicators that influence this interactive process of experiences, wisdom, and knowledge by development, work, stability, in the environment where they operate. There are factors that influence and determine that the development of a social conglomerate does not correspond to the number of professionals who graduate from university classrooms. To determine the development is growing or not, the possible causes generate it has analyzed and secondly, strategies have proposed in which the main actors of the change participate. The province of Manabí has characterized by significant economic activity in the agricultural field, with the ideal conditions to originate growth and development; however, there are high levels of unemployment. In the present work an analysis of the registry of the professionals that graduates of the Faculty of Mathematical, Physical and Chemical Sciences, of the Technical University of Manabí, is made, with aims of professional occupation, in order to design a strategy that propitiates the development local of the province.
\end{abstract}

e-ISSN: 2550-7001, p-ISSN: 2550-701X ๑ Copyright 2019. The Author. SS Journals Published by Universidad Técnica de Manabí. This is an open-access article under the CC BY-SA 4.0 license

(https://creativecommons.org/licenses/by-sa/4.0/) All rights reserved.

\footnotetext{
a MsC, Engineer in administration of FCMFQ. Universidad Técnica de Manabí, Portoviejo, Ecuador

b MsC. Teacher of the Faculty of Philosophy-. Universidad Técnica de Manabí, Portoviejo, Ecuador

c PhD. Language Teacher. Universidad Técnica de Manabí, Portoviejo, Ecuador

d MsC. Civil Engineer, Dean of FCMFQ, Universidad Técnica de Manabí, Portoviejo, Ecuador

e PhD. Professor of the Electrical Engineering career of the FCMFQ Universidad Técnica de Manabí, Portoviejo, Ecuador
} 


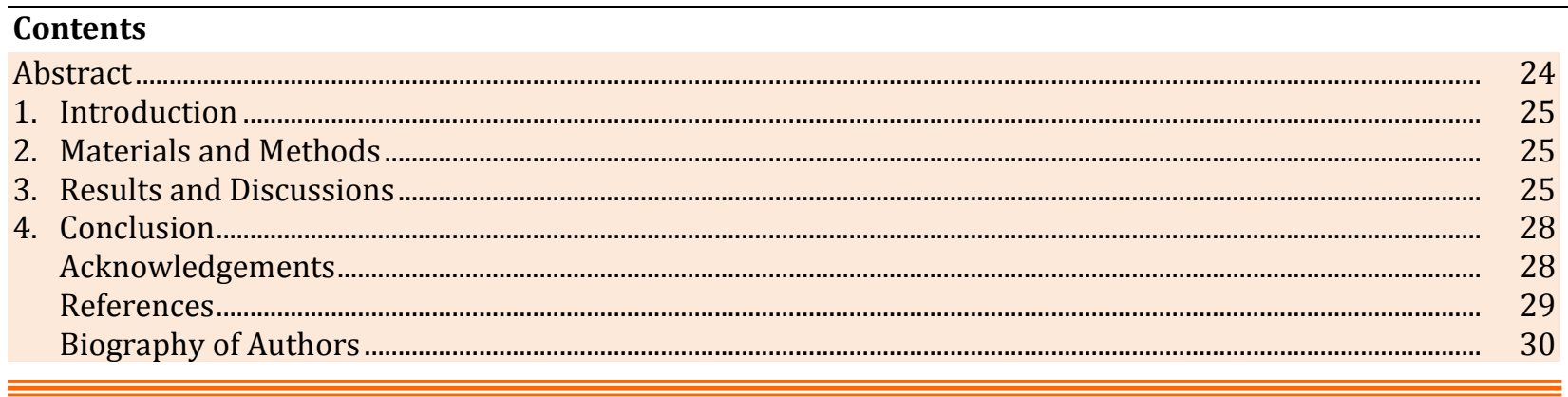

\section{Introduction}

Local development is fundamental in the evolution of society since in the localities are sources of food, water, air and human resources in full production as the main entity and one of the basic elements in its sustainability and sustainability. The basic training of human resources should be oriented to an education that is capable of allowing the individual to value each element that surrounds it so that they can give an adequate job to each resource and achieve sustenance with what counts in their environment.

The university plays an essential role in this training, through the processes of undergraduate training, linkage, and research, and it is with these elements that the basic functions for sustainability are sustained, the province's development sustainability and thus design strategies that allow Students know and be active participants in knowing their resources and how to exploit them. Another of the essential aspects of the University is to strengthen the capacities, to lead strategies with an improvement in the practices that allow the precision of adequate methods in the training of human resources (Rodríguez, 2006).

The University, among its basic functions such as teaching and research, must achieve adequate guidance and pay special attention to local development by training students with a vision of entrepreneurs (Uribe, 2013). The objective of this document is to know the contributions made by the Faculty of Mathematical, Physical and Chemical Sciences (FCMFQ), in the training of capacities and leadership in the human resources that come out of their classrooms, the same ones that contribute to the economic-social development of the province, enhancing this resource in the areas of the territory, in such a way that it continues to have good productivity; but with knowledge of its main actors.

The Technical University of Manabí (UTM) is part of the educational universe of the province, hence, together with other centers of higher education, is the architect of undergraduate education, and thus within their programs and curricula appropriate strategies are contemplated in protection of the resources of the locality; hence the FCMFQ, is one of the academic units that provides training in human resources, currently with four thousand six hundred students, integrated into five engineering careers, where all aim to train engineers who are able to develop their knowledge and capacities for the benefit of the territory, enhancing local development through the professional training it imparts (Perez et al., 2017: Gamez et al., 2017).

\section{Materials and Methods}

To carry out the research, the database of the graduate students from 2008 to the present time, of the five FCMFQ careers, as well as of the projects approved by career, was taken as sample, considering that some of these projects approved have not been materialized at present, with the presentation of their results.

\section{Results and Discussions}

The FCMFQ has contributed engineers so that they are incorporated to the local development of the province in different careers or specialties, a study that has been made from a database, conserved in the Secretariat of the Dean's Office of the FCMFQ and detailed in Table 1, which shows the number of graduates by Careers.

Loor, Y. C., Zambrano, J. L. Ávila, Loor, M. D. C., Viteri, C. G. V., \& Gámez, M. R. (2019). Professional training incident in local development. International Journal of Social Sciences and Humanities, 3(2), 24-30. 
Table 1

Graduates by Careers Period 2008-2018

\begin{tabular}{|c|c|c|c|c|c|c|c|c|c|c|c|}
\hline \multirow{2}{*}{ Career } & \multicolumn{11}{|c|}{ Year } \\
\hline & 2008 & 2009 & 2010 & 2011 & 2012 & 2013 & 2014 & 2015 & 2016 & 2017 & 2018 \\
\hline Civil & 119 & 142 & 118 & 141 & 129 & 299 & 55 & 209 & 167 & 106 & 145 \\
\hline Mechanical & 9 & 13 & 34 & 40 & 28 & 25 & 16 & 22 & 28 & 34 & 27 \\
\hline Chemistry & 0 & 5 & 22 & 40 & 35 & 55 & 27 & 47 & 47 & 47 & 49 \\
\hline Electricity & 37 & 39 & 43 & 67 & 32 & 60 & 8 & 27 & 33 & 30 & 27 \\
\hline Industrial & 9 & 17 & 39 & 47 & 12 & 50 & 9 & 29 & 22 & 40 & 21 \\
\hline Total per faculty & 174 & 216 & 256 & 335 & 236 & 489 & 115 & 334 & 297 & 257 & 269 \\
\hline
\end{tabular}

As you can see the career of Civil Engineering has the largest number of professionals that have contributed to the development of the province, this can be assessed as positive considering that the growth of civil infrastructure in the provincial capital, Portoviejo, has been increasing, from the catastrophic earthquake event that occurred on April 16, 2016. The studies corresponding to the "Graduate Monitoring" Program indicate that not all graduates have a job, a factor that affects the process of local development in the region, determining that There is a strategy that helps the recent graduate to join professional work life.

This aspect of unemployment among graduates is reflected in other Latin American countries, such as Mexico (Weller, 2015; Jacinto, 2001). This situation makes the graduate change his projection and vision to life so that new projects are created in the environment of his personal life and as trained entrepreneurs, where many of those projects that they assume, run on their own and where they face the challenge to look for alternatives from taking advantage of the needs of their environment by promoting small businesses.

As a contribution of these 10 years evaluated, the FCMFQ has incorporated to the development of the province a total of 2978 trained professionals. Figure 1 shows the total professional graduates by careers, observing the incidence in graduates of the Civil Engineering Degree in this result; this means that the constructive development of the region demands this specialty, demonstrated in the growth of the civil infrastructure of the province as an important contribution to local development

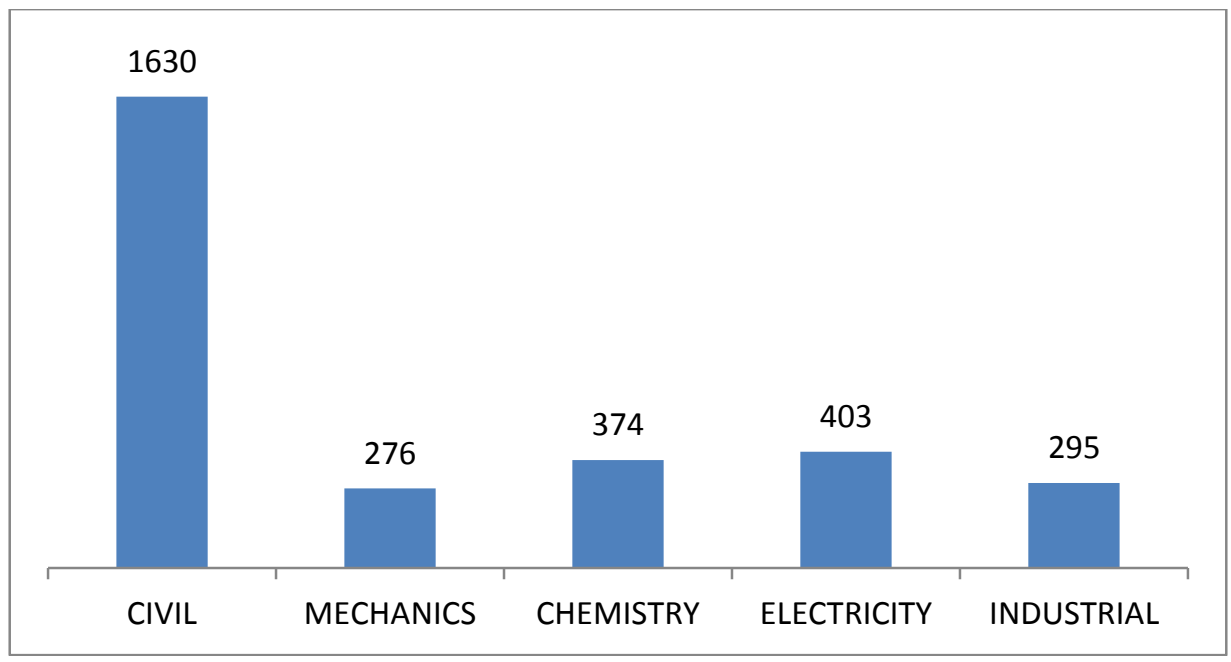

Figure 1. Number of graduates by careers in the period 2008-2018

The earthquake that occurred in 2016, caused great destruction throughout the province, which has influenced in some way, the insertion of professionals graduated from the classrooms of the FCMFQ in public institutions and private companies, most notably in the Decentralized Autonomous Governments, GAD, which has allowed newly graduated engineers to find jobs according to their professional training.

In this process of degree also perceives in a negative way the percentages of graduates in the Careers of Mechanical Engineering and Industrial Engineering, where the levels have been low, reason why it is 
interesting to reflect, why the area of specialty in Industry, propitious for the agroindustrial development of the province of Manabí, provides a minority of Engineers trained to face the difficulties facing this sector, which is underdeveloped, and where many products are not processed and others are exported to the international market with low value, which then they return processed with high costs to internal consumption.

This leads us to devise provincial strategies where all the actors of public and private provincial development intervene so that public policies are generated, which guarantee legal, labor, economic and business security, which encourage agro-industrial growth, with the support of the academy. in the fields of research, development, and innovation that pay tribute to local development, in order that these careers contribute significantly.

Figure 2 shows the number of graduates per year, as observed in civil engineering in 2013 had its largest number of graduates.

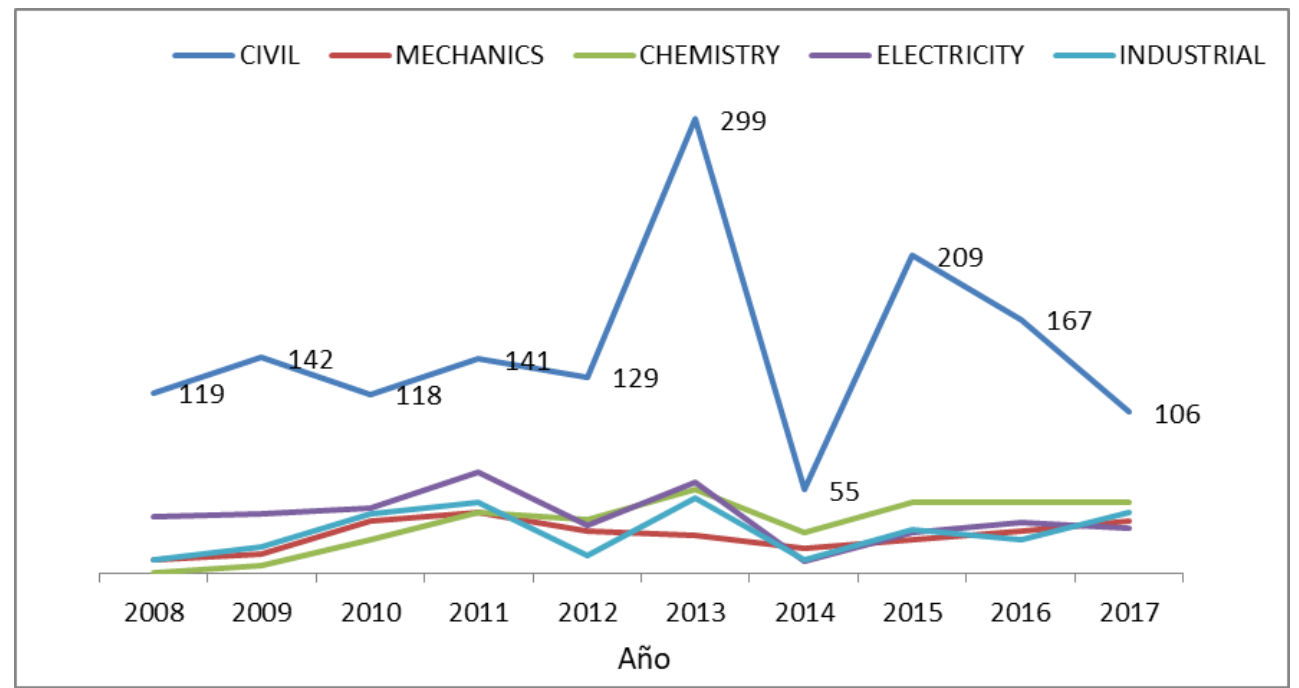

Figure 2. Number of graduates per year and careers

In recent years, the Ecuadorian university has designed as a strategy to ensure that students graduate in the times established in the regulations. This has allowed 154 students to professionalize in 2018, as shown in figure 3, where it has been observed that the Civil Engineering Degree continues to be the career with the highest number of graduates.

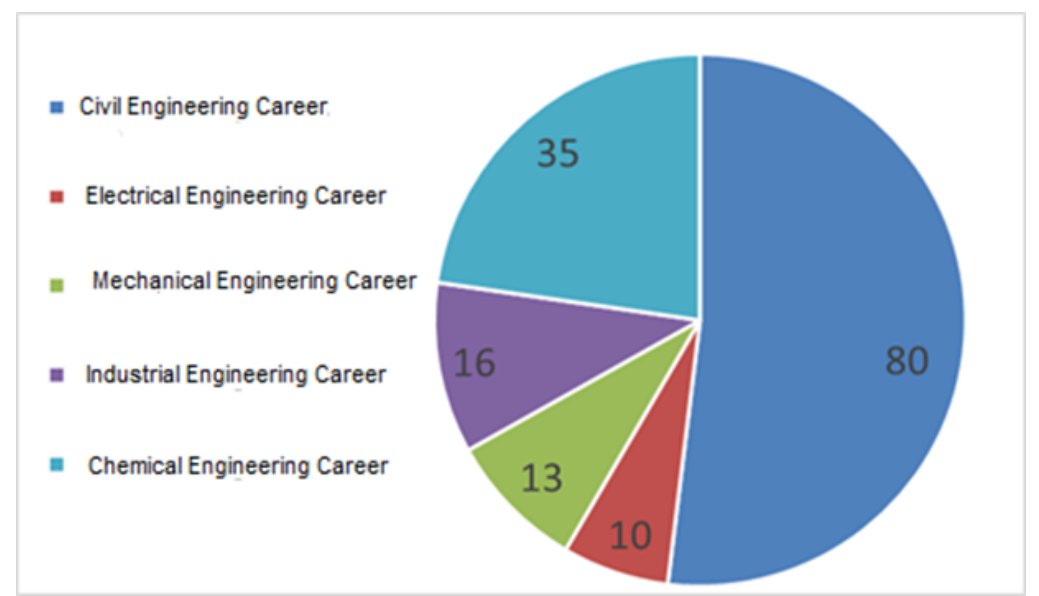

Figure 3. Graduates in the year 2018 by careers

Loor, Y. C., Zambrano, J. L. Ávila, Loor, M. D. C., Viteri, C. G. V., \& Gámez, M. R. (2019). Professional training incident in local development. International Journal of Social Sciences and Humanities, 3(2), 24-30. 
Research has the possibility of favoring the development of skills and the solution of new facts, in accordance with advances in technology, technology and thinking (Bijarro, 2007). It is interesting to assess the types of graduation modalities of students when making an analysis of these; it has observed that the most used is the research, in Figure 4 there is a graph showing the number of graduates for the item studied.

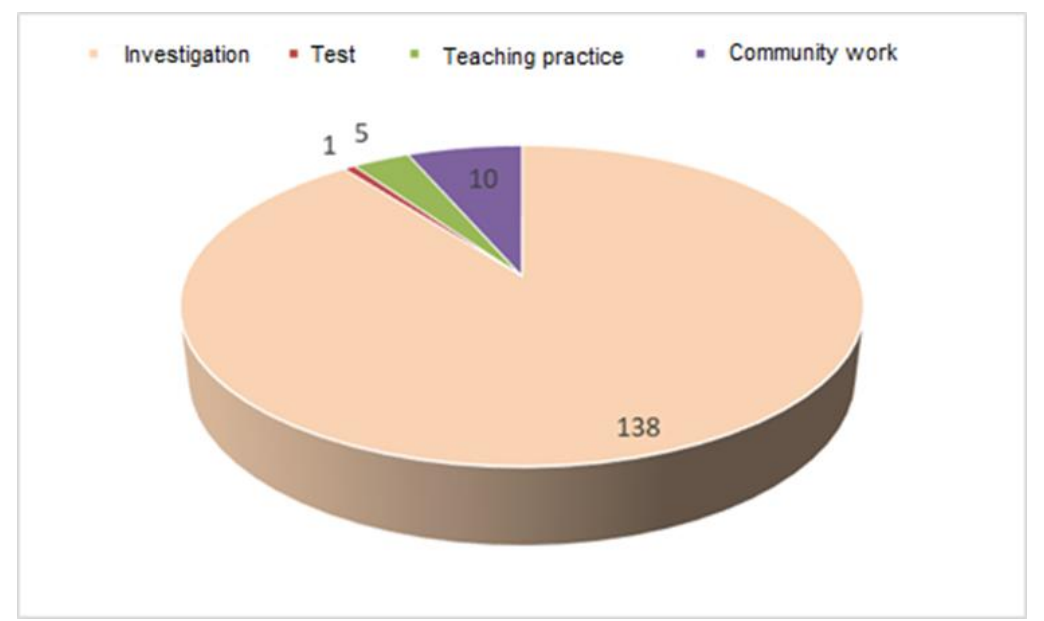

Figure 4. Number of graduates according to modality

As the most used research modality, a projective analysis could be made of students orienting their knowledge to the problems that exist in the province, and in this sense, local development has enhanced from which professionals can develop ventures that meet the needs that have envisaged for the growth of the province.

These results are the product of the regulations promulgated by the Higher Education Council regarding the increase of research faculty with a Ph.D. level, as well as the strengthening and promotion of research through public policy guided by the government and materialized by the priority. That has given to the improvement of higher education in the country and to the development of scientific knowledge, contributing to the improvement of substantive processes in the quality of universities (Rivera et al., 2017), and to help them to be able to influence the process of local development.

\section{Conclusion}

The university professionals graduated in the FCMFQ in their research projection, will empower themselves and contribute with their knowledge to the local development of their territory, improving the socio-economic, cultural conditions of the province where the Faculty and the University play an important role in the academic training, culturalization, fundamental in its application to territorial knowledge and universality.

\section{Acknowledgments}

All the authors are grateful for their collaboration in the search for information to develop the article 


\section{References}

Bijarro, F. (2007). Strategic development for scientific research. Autonomous University of Tamaulipas .

Gamez, M. R., Perez, A. V., Sera, A. S., \& Ronquillo, Z. M. (2017). Renewable energy sources and local development. International Journal of Social Sciences and Humanities, 1(2), 10-19. https://doi.org/10.29332/ijssh.v1n2.31

Jacinto, C. (2001). Contexts and social actors in the evaluation of youth training programs. UIA; UNICEF; Cinterfor / ILO; CONASEP; https://www.oei.es/historico/etp/estrategias_educativas_insercion_productiva.pdf

Perez, A. V., Gamez, M. R., Viteri, C. G. V., \& Quiroz, A. M. V. (2017). Community power as a driving force for sustainable local development. International Research Journal of Engineering, IT \& Scientific Research, 3(4), 8-19.

Rivera, T. (1992). Tomás Rivera: the complete works. Arte Publico Press.

Rodriguez, A., \& Rodriguez, Y. (2015). Metaphors for today's leadership: VUCA world, millennial and "Cloud Leaders". Journal of Management Development, 34(7), 854-866.

Uribe T Juan, V. (2013). Local and business development: Training as a basic factor for. 644-677 http://dx.doi.org/10.3926/ic.272

Weller, J. (2015). Educational and training strategies for social and productive integration.

Loor, Y. C., Zambrano, J. L. Ávila, Loor, M. D. C., Viteri, C. G. V., \& Gámez, M. R. (2019). Professional training incident in local development. International Journal of Social Sciences and Humanities, 3(2), 24-30. 


\section{Biography of Authors}

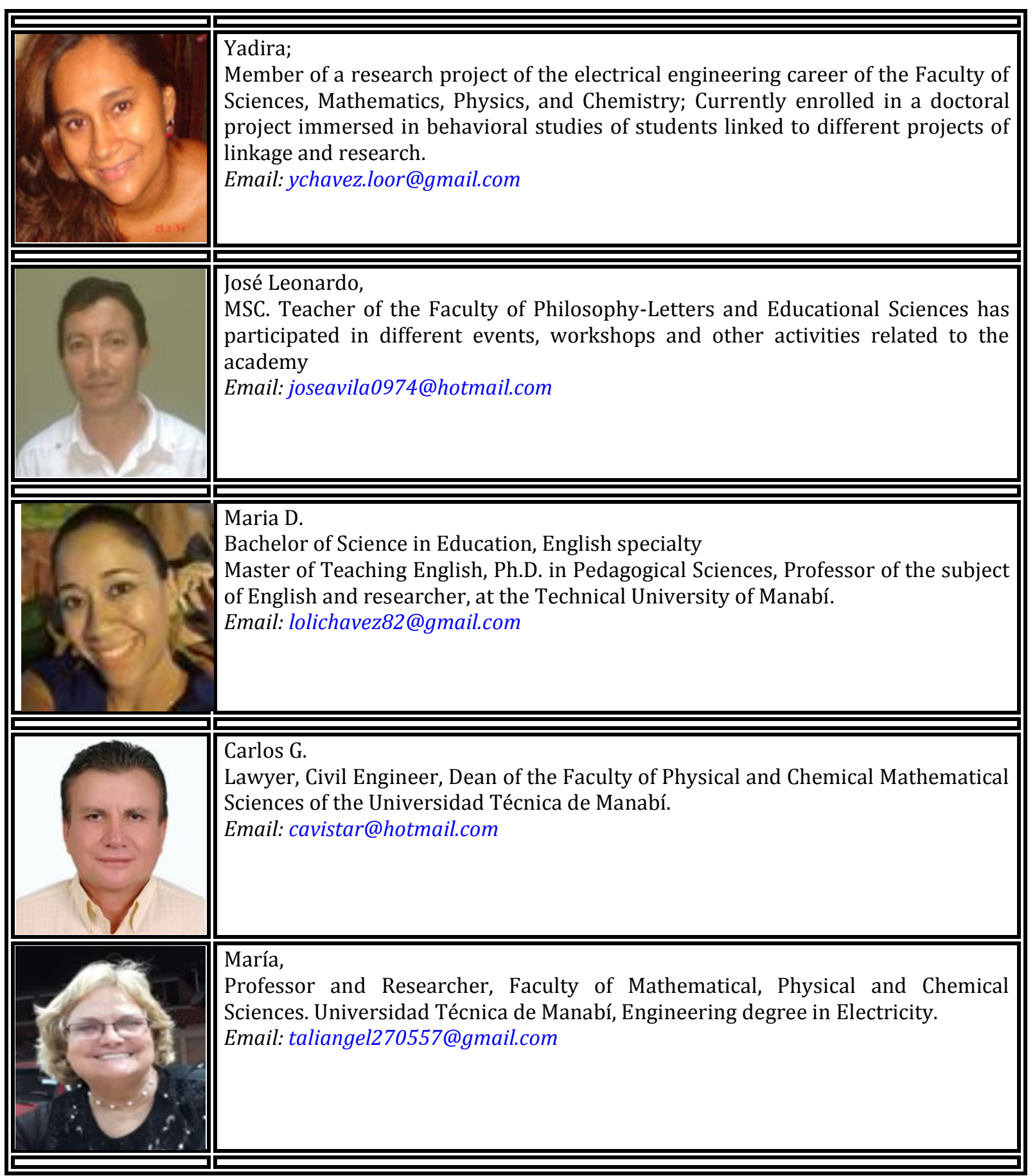

